\title{
Biological Control of Grape Powdery Mildew Using Mycophagous Mites
}

\author{
Greg English-Loeb and Andrew P. Norton, Department of Entomology, Cornell University, New York State Agri- \\ cultural Experiment Station, Geneva, NY 14456; and David Gadoury, Robert Seem, and Wayne Wilcox, Depart- \\ ment of Plant Pathology, Cornell University, New York State Agricultural Experiment Station, Geneva, NY 14456
}

\begin{abstract}
English-Loeb, G., Norton, A. P., Gadoury, D., Seem, R., and Wilcox, W. 2007. Biological control of grape powdery mildew using mycophagous mites. Plant Dis. 91:421-429.

We evaluated the efficacy of a mycophagous tydeid mite, Orthotydeus lambi, in controlling grape powdery mildew on mature vines of nine different grape cultivars and one unnamed hybrid grown in an experimental vineyard over a 3-year period. $O$. lambi became well established on all vines where they were released. However, some cultivars supported higher densities than others, depending on, among other factors, the presence and abundance of leaf trichomes in vein axils (domatia). The establishment of $O$. lambi substantially reduced powdery mildew on foliage and fruit, although the magnitude of disease suppression was greater on some grape genotypes than others, depending on mite density and innate susceptibility to grape powdery mildew. Treatments where $O$. lambi was used alone were as effective as fungicide. Significantly better disease control was found in treatments with both mites and fungicides. The mass of pruning material and leaf photosynthetic rates were significantly greater for vines with $O$. lambi, fungicide, or a combination of mites and fungicide compared with untreated vines. The combination of mites and fungicide resulted in significantly greater yield than mites or fungicide alone. Our results illustrate the potential of $O$. lambi for biological control of grape powdery mildew but also highlight limitations related to differences among grape genotypes in innate susceptibility to mildew and suitability for mites.
\end{abstract}

Additional keywords: Tydeidae, Uncinula necator, viticulture, Vitis labrusca, V. riparia, V. vinifera

Uncinula necator (syn. Erysiphe necator), the causal agent of grape powdery mildew, is the most destructive pathogen of grapes worldwide, including the northeastern United States (27,33). Without intensive use of fungicides, grape powdery mildew significantly reduces vine health, grape quality, and yield, and causes severe economic loss (29). Nearly all grapes grown commercially receive several fungicide applications each year to control powdery mildew (26). Because of the considerable expense of such intensive fungicide use and the demonstrable propensity of $U$. necator to develop resistance to fungicides within a few years after their widespread commercial deployment $(12,17$, $32,34)$, there has been considerable interest, but limited success, in finding biological approaches that provide commercially relevant levels of suppression of powdery mildews. Several species of parasitic or antagonistic fungi, including Verticillium lecanii, Ampelomyces quisqualis, Sporoth-

Corresponding author: Greg English-Loeb E-mail: gme1@cornell.edu

Current address of Andrew P. Norton: Department of Bioagricultural Sciences and Pest Management, Colorado State University, Fort Collins, CO 80523.

Accepted for publication 19 October 2006.

doi:10.1094/PDIS-91-4-0421

(c) 2007 The American Phytopathological Society rix flocculosa, and Tilletiopsis pallescens, have been examined for their ability to suppress powdery mildews of grapevine and other crops $(3,5,7,13,14,31)$. While the results from these trials have been promising, there are several practical barriers to widespread commercial adoption in viticulture and elsewhere. First, the above agents must be applied repeatedly (18). Second, while all of the above are fungi, all require a more narrow range of environmental conditions than do most powdery mildews. In particular, the above biocontrol organisms require high humidity or surface wetness for growth and reproduction (30). In contrast, most powdery mildews, in particular U. necator, grow remarkably well without high relative humidity or surface wetness (1). Finally, because the biocontrol agents described above are fungi, they are sensitive to many of the same fungicides used to control powdery mildew (2). This is even more problematic in agro-ecosystems harboring a complex array of several pathogenic fungi such as grapes (15), which may require intensive use of a variety of broadspectrum fungicides.

Recently, we discovered a mycophagous mite, Orthotydeus lambi (Baker), that is able to effectively suppress the development of powdery mildew on wild riverbank grape, Vitis riparia Michx., and other grape species. O. lambi is a common species of tydeid mite (Fig. 1), occurring on a wide range of perennial plant species throughout the Northeast (9). It can be very abundant on riverbank grape in the northeastern United States as well as on other tree and shrub species (9). The mite family to which $O$. lambi belongs (Tydeidae) is reported to feed on a variety of organisms including fungi, pollen, and small arthropods (19). Mendel and Gerson (22) showed that sooty mold increased on citrus where the tydeid mite Lorryia formosa Cooreman was removed with an acaricide. Abundance of the tydeid mite Tydeus caudatus Dugés was positively correlated with severity of grape downy mildew, caused by Plasmopara viticola (Berk. \& Curtis ex de Bary) Berl \& de Toni, in Italian vineyards, and populations of the mite declined when downy mildew was controlled with fungicides not harmful to the mites (8). Tydeid mites are found in numerous habitats including ground litter, moss, straw, stored grain, and the bark, stems, and leaves of plants. Specifically, O. lambi uses specialized mouthparts (i.e., needle-like chelicera) to suck nutrients from food items (19), and has been shown to inflict considerable damage to $U$. necator (21). However, experimental data on interactions of $O$. lambi with fungi under field conditions were limited until recently $(10,21,25)$.

Our initial interest in $O$. lambi was stimulated by the observation that grape powdery mildew was rare on $V$. riparia growing in the wild even though $V$. riparia is moderately susceptible under greenhouse conditions. However, subsequent manipulative experiments using potted $V$. riparia vines clearly showed that the presence of $O$. lambi, at approximately natural densities, resulted in significant reductions of powdery mildew on foliage $(9,25)$. Additional experimentation in the laboratory and vineyard provided insights into the mechanisms by which suppression of the disease occurs, including observations of direct feeding damage on fungal hyphae and conidia (21).

A multiyear field study, with different grape species planted in an experimental vineyard, showed that $O$. lambi is a significant predator of $U$. necator, resulting in reduced disease development on foliage (10). Populations of $O$. lambi were greatly influenced by grape leaf morphology, particularly the presence and size of domatia, nonglandular trichomes in the vein axils on the undersides of leaves (25). Grape species with large domatia supported greater populations of $O$. lambi than species that lacked or had small domatia. 
Although the foregoing results indicated some potential for $O$. lambi to provide biological control of grape powdery mildew, many issues related to its practical use remained unresolved. In 1998, we initiated a field trial to address the following questions: (i) Can $O$. lambi provide commercially relevant control of grape powdery mildew on leaves and fruit at the vineyard level? (ii) How does control by $O$. lambi compare with that by conventional fungicides? (iii) Can these two control options be used in combination, and can the mite survive in the context of a typical commercial fungicide program? (iv) What are the consequences of relying upon $O$. lambi verses fungicides for managing powdery mildew on measures of plant productivity? (v) To what extent does grape cultivar influence $O$. lambi populations and their impact on mildew and productivity?

\section{MATERIALS AND METHODS}

We established an experimental vineyard in the spring of 1998 at the New York State Agricultural Experiment Station in Geneva, NY, that included three different cultivars of the European grapevine $V$. vinifera L. ('Chardonnay', 'Cabernet Franc', and 'Cabernet Sauvignon'), two cultivars of the North American species $V$. labrusca L. ('Concord' and 'Niagara'), and five interspecific hybrid cultivars ('Aurora', 'Cayuga White', 'Seyval', 'Baco Noir', and an unnamed Vitis interspecific hybrid). The hybrid cultivars, except for the unnamed one, were developed by grape breeders and involve complex combinations of $V$. vinifera and several North American Vitis species (28). 'Baco Noir's' parentage includes $V$. riparia and $V$. vinifera, while 'Aurora', 'Cayuga White', and

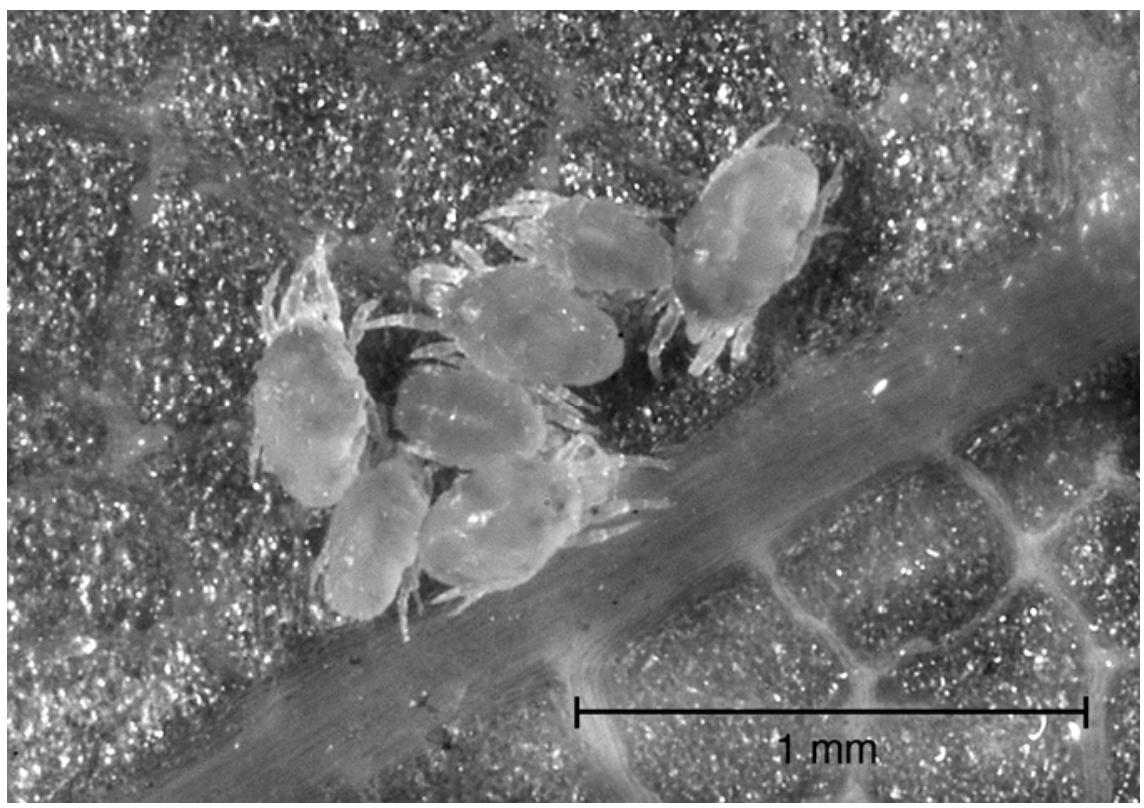

Fig. 1. Photograph of a cluster of adult mycophagous tydeid mites Orthotydeus lambi on a Vitis riparia leaf. Mite length is approximately 0.3 to $0.4 \mathrm{~mm}$.

'Seyval' all include $V$. vinifera, $V$. aestivalis Michx., and V. rupestris Scheele, as well as other North American species. The unnamed hybrid is part of the USDA germ plasm collection and is reported as $\mathrm{V}$. riparia. However, foliar and fruit characteristics suggest it is a hybrid with $V$. labrusca (23). The different cultivars and the unnamed hybrid were chosen because they are representative of grapes grown commercially in eastern North America and show considerable variation both in their resistance to grape powdery mildew and in the morphology of their leaves $(10,27,28)$. Cultivars were obtained from nurseries as 1-year-old rooted vines, while the unnamed hybrid was obtained from the germ plasm collection of the USDA Grapevine Germplasm Repository Collection at the New York State Agricultural Experiment Station in Geneva. The unnamed hybrid was collected as 1-year-old hardwood cuttings that were subsequently rooted over the winter in the greenhouse before spring planting. Small plots (two vines) of each grape cultivar or unnamed hybrid were either infested with $O$. lambi or kept free of $O$. lambi (factor 1) and either treated with grape powdery mildew fungicide or not treated (factor 2) using a completely randomized block experimental design with six replicates per treatment combination. Vines within a plot were spaced $2.1 \mathrm{~m}$ apart, while plots within a row were spaced every $5.2 \mathrm{~m}$. Thus, the second vine of one plot was approximately $3 \mathrm{~m}$ from the first vine of the next plot. There were 13 plots per row and 7 rows per block with $2.7 \mathrm{~m}$ between rows. Blocks were separated by $7.5 \mathrm{~m}$. Vines were trained using a modified umbrella kniffen system. Training was completed during the 2000 growing season. After

422 Plant Disease /Vol. 91 No. 4 establishment, vines were pruned to a set number of nodes in early spring prior to budbreak (5 to 15 nodes per kilogram of pruned wood, depending on grape genotype).

Leaves from local wild populations of $V$. riparia containing high densities of $O$. lambi were used to initially infest vines assigned to receive $O$. lambi in July 1998 . The mean number of adult and immature O. lambi per leaf, based on a subsample of collected leaves, was 117 ( $\mathrm{SE}=19.7, n=$ 25). We used a twist tie to attach leaves containing $O$. lambi to release vines. The number of leaves was adjusted to vine size so that we released roughly equal densities of mites per leaf. Hexythiazox (Savey 50WP, Gowan Company, Yuma, AZ) was applied at a rate of $374 \mathrm{~g} / \mathrm{ha}$ approximately three times each season to prevent establishment of tydeid mites on vines not assigned to receive them. Experiments using potted vines indicated that hexythiazox has no impact on development of grape powdery mildew (G. English-Loeb, unpublished data). For vines assigned to receive fungicides for powdery mildew control in 2000 and 2001, myclobutanil (Nova 40W, Dow AgroSciences, Indianapolis, IN), a fungicide known to be relatively harmless to $O$. lambi but effective against powdery mildew, was applied at a rate of $230 \mathrm{~g} / \mathrm{ha}$ approximately five times per season. In 2001, fenarimol (Rubigan EC, Gowan Company), another fungicide in the same chemical class as myclobutanil (sterol biosynthesis), was applied at a rate of 187 $\mathrm{ml} /$ ha five times during the season. All vines were treated one to three times during the season with the Oomycete-specific fungicide mefenoxam (Ridomil Gold EC, Syngenta Crop Protection, Greensboro, $\mathrm{NC})$ at $233.7 \mathrm{ml} / \mathrm{ha}$ to prevent development of grape downy mildew caused by $P$. viticola, as defoliation by this pathogen could confound assessments of the incidence and severity of powdery mildew. Previous studies indicated that this fungicide has no impact on $O$. lambi or U. necator (G. English-Loeb, unpublished data). Pesticides were applied using a hooded boom sprayer in the equivalent of 935 liters per hectare of water.

Densities of $O$. lambi were assessed three times (June, July, and August) each year from 2000 through 2002. At each assessment, we collected two leaves per replicate plot (one per vine), arbitrarily selected from the middle portion of the shoot. Previous unpublished research on the distribution of $O$. lambi on grape shoots through the season indicated that mites become randomly distributed after the first month of growth. The leaves were bagged, returned to the laboratory, and examined for $O$. lambi mites using a dissecting microscope.

Incidence and severity of leaf infection by grape powdery mildew was estimated in August of each field season. Leaf infection 
was evaluated in the field by visually estimating the percentage of leaf area covered with mycelium from 12 leaves per replicate plot (three leaves per shoot, starting at the eighth leaf from the base, two shoots per vine). Shoots were chosen arbitrarily.

Infection on fruit clusters was assessed once each field season for 2000, 2001, and 2002 during late July or early August by estimating the percentage of the surface area infected with mildew of 10 clusters per plot (five per vine, arbitrarily chosen from five different shoots per vine). Vine productivity, as influenced by grape cultivar and treatment, was assessed in three ways. First, the mass of pruned wood was determined for each two-vine plot following the 2000 and 2001 growing seasons as a measure of growth and productivity. Second, leaf photosynthesis rates were assessed once each year in late summer from a subset of plots for the 2000 and 2001 growing seasons. Rate of $\mathrm{CO}_{2}$ uptake was measured from a $2.5 \mathrm{~cm}^{2}$ area of a single, midshoot leaf from each vine using an infrared gas analyzer photosynthesis system (TPS-1, PP Systems, Haverhill, MA) with three to five replicate plots assessed per treatment for each cultivar. Third, all fruit was harvested from each vine in mid-September to early October in 2001 and 2002 and weighed to the nearest $0.05 \mathrm{~kg}$ using a portable platform scale.

We examined the influence of treatment (with or without $O$. lambi and with or without powdery mildew fungicide), grape cultivar, year, and block on tydeid mite densities, severity of powdery mildew on leaves and fruit, vine pruning weight, single leaf photosynthesis, and yield using SAS PROC MIXED (SAS version 8, SAS Institute, Cary, NC) with repeated measures and a compound symmetric covariance structure (20). Tydeid mite treatment, fungicide treatment, grape cultivar, and year were defined as fixed effects variables, and block was defined as a random effects variable. Leaf and fruit mildew, mite density, pruning weight, and yield were natural-log transformed after adding 1 (mildew and mite density) or 0.1 (pruning weight) or 0.0 (yield) prior to analysis to meet assumptions of analysis of variance. Degrees of freedom for all $F$ and $t$ tests were estimated using the Satterthwaite approximation (20). Contrasts between least-square means were made using the LSMEANS statement in SAS (SAS version 8).

\section{RESULTS}

Mite densities. We were successful both in establishing $O$. lambi on release vines and in keeping the mites off of nonrelease vines. Densities did not exceed 1 mite per leaf on nonrelease vines (data not shown) indicating the miticide used was quite effective. On the other hand, densities on release vines not treated with a powdery mildew fungicide, averaged over the dif- ferent grape cultivars and unnamed hybrid, exceeded 10 per leaf in 2000, 25 per leaf in 2001, and just under 15 in 2002 (Fig. 2A). We did not detect a statistically significant effect of the powdery mildew fungicide on
$O$. lambi densities at alpha $=0.05$ level $\left(F_{1,218}=3.13, P=0.078\right.$, Table 1$)$. The highest mite density, over 30 per leaf, averaged over 3 years, was observed on the Vitis interspecific hybrid grape 'Baco Noir'
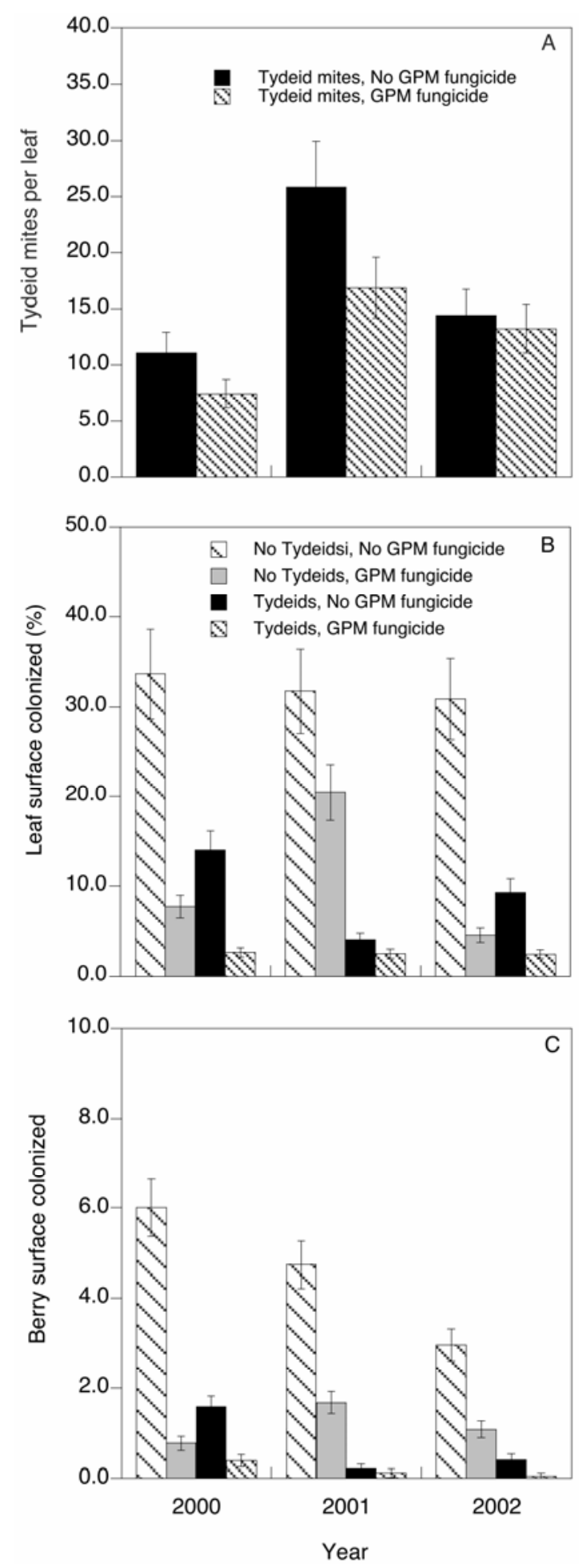

Fig. 2. A, Density of the mycophagous tydeid mite Orthotydeus lambi on vines that received $O$. lambi alone or $O$. lambi plus grape powdery mildew fungicide (GPM fungicide). B, Mean percentage of leaf area covered with grape powdery mildew for control vines lacking $O$. lambi or GPM fungicide, vines with only GPM fungicide, vines with only $O$. lambi, and vines with both $O$. lambi and GPM fungicide. C, Mean percentage of berry surface area covered with grape powdery mildew for control vines lacking $O$. lambi or GPM fungicide, vines with only GPM fungicide, vines with only $O$. lambi, and vines with both $O$. lambi and GPM fungicide. Values reported for 2000-2002. The mean values were computed by taking the anti-log of log-transformed values. Vertical bar indicates anti-log of $\log$ mean \pm 1 log-transformed standard error. 
(Fig. 3). This was significantly greater than in other cultivars (all pairwise contrasts significant, $P \leq 0.025$ ). The two native $V$. labrusca cultivars ('Niagara' and 'Concord') and the interspecific hybrid 'Seyval' had the lowest densities, fewer than 10 mites per leaf averaged over the 3 years, while densities were intermediate on the other cultivars (Fig. 3).

Foliar infections. The presence of $O$. lambi alone significantly reduced severity of grape powdery mildew on foliage all 3 years of the study (Table 1, Fig. 2B). The magnitude of the reduction of mildew in response to $O$. lambi release ranged from $87 \%$ in 2001 to $58 \%$ in 2000 relative to control vines that lacked both tydeid mites and powdery mildew fungicide. The powdery mildew fungicides alone also significantly reduced foliar mildew in all 3 years (Table 1, Fig. 2B) at magnitudes similar to those of mites alone, although in 2000 and 2002, the fungicide treatment had significantly lower leaf mildew than tydeid mites alone, while in 2001 the reverse was true (three-way interaction term mite*fungicide* year, $F_{2,439}=3.01, P=0.05$, Table 1 ). The combination of tydeid mites and powdery mildew fungicides resulted in significantly lower levels of leaf mildew compared with other treatment combinations for each year of the study (all pairwise contrasts between mite plus fungicide treatment and other treatment combinations significant within a given year, $P<$ 0.025 , Fig. 2B). The different grape cultivars and the unnamed hybrid varied significantly in susceptibility to foliar powdery mildew (no powdery mildew fungicide, no $O$. lambi), as would be expected, with cultivars of $V$. vinifera showing the greatest levels of mildew while the $V$. labrusca cultivars showing the least (Table 1, Fig. 4). Although the presence of O. lambi resulted in significant reductions in leaf mildew for all cultivars, the amount of suppression did vary among cultivars and the unnamed hybrid as indicated by the significant interaction between mite release and cultivar $\left(F_{9,250}=2.82, P=\right.$ $0.0035)$. Foliar infection was reduced by over $75 \%$ for all of the cultivars and the unnamed hybrid with the exception of $V$. labrusca 'Concord' and the hybrids 'Sey- val' and 'Aurora'. Not surprisingly, there was a significant, positive relationship between density of $O$. lambi on release vines for a particular cultivar or the unnamed hybrid and percent reduction in mildew (averaged over the 3 years, $F_{1,8}=$ 7.12, $P=0.02)$.

Fruit infection. Overall treatment effects on cluster infection were, for the



Fig. 3. Density of the mycophagous tydeid mite Orthotydeus lambi for nine different grape cultivars and one unnamed hybrid over the 3 years data were collected (2000-2002). Mean values were computed by taking the anti-log of log-transformed values. Vertical bar indicates anti-log of log mean \pm 1 log-transformed standard error.

Table 1. Mixed model repeated measures analysis of variance examining the effect of release of the tydeid mite Orthotydeus lambi, grape powdery mildew fungicide, grape cultivar, year, and interactions as fixed effects variables and block as a random effects variable on density of $O$. lambi per leaf, proportion leaf area infected with grape powdery mildew, and proportion of berry surface area infected with grape powdery mildew (all dependent variables log transformed after adding 1) for 2000-2002

\begin{tabular}{|c|c|c|c|c|c|c|}
\hline \multirow[b]{2}{*}{ Source } & \multicolumn{2}{|c|}{ Tydeid mites } & \multicolumn{2}{|c|}{ Leaf mildew } & \multicolumn{2}{|c|}{ Cluster mildew } \\
\hline & df & $F$ value & df & $F$ value & df & $F$ value \\
\hline \multicolumn{7}{|l|}{ Fixed } \\
\hline Tydeid mite release & 1,218 & $2045.4 * * * \mathrm{a}$ & 1,250 & $264.0 * * *$ & 1,217 & $286.3 * * *$ \\
\hline Fungicide & 1,218 & 3.1 & 1,250 & $221.4 * * *$ & 1,217 & $140.8 * * *$ \\
\hline Grape cultivar & 9,218 & $13.2 * * *$ & 9,250 & $19.0 * * *$ & 9,217 & $96.0 * * *$ \\
\hline Year & 2,414 & $56.3 * * *$ & 2,439 & $5.3^{* *}$ & 2,405 & $17.6^{* * *}$ \\
\hline Tydeid $*$ fungicide & 1,218 & $15.0 * * *$ & 1,250 & 2.4 & 1,217 & $32.1 * * *$ \\
\hline Tydeid $*$ cultivar & 9,218 & $6.8 * * *$ & 9,250 & $2.8 * *$ & 9,217 & $36.8^{* * *}$ \\
\hline Tydeid $*$ year & 2,414 & $58.2 * * *$ & 2,439 & $35.5 * * *$ & 2,405 & $18.8^{* * *}$ \\
\hline Fungicide $*$ cultivar & 9,218 & 1.1 & 9,250 & 1.3 & 9,217 & $10.6^{* * *}$ \\
\hline Fungicide $*$ year & 2,414 & 2.2 & 2,437 & $36.5 * * *$ & 2,405 & $18.5^{* * *}$ \\
\hline Year $*$ cultivar & 18,414 & 1.6 & 18,439 & $3.7 * * *$ & 18,405 & $4.1 * * *$ \\
\hline Tydeid $*$ fungicide $*$ cultivar & 9,225 & 0.7 & 9,259 & 1.0 & 9,226 & $2.7 * *$ \\
\hline Fung. $*$ year $*$ cultivar & 18,414 & 1.2 & 18,439 & 0.9 & 18,405 & $3.9 * * *$ \\
\hline Tydeid $*$ year $*$ cultivar & 18,414 & 1.2 & 18,439 & 1.4 & 18,405 & $3.4^{* * *}$ \\
\hline Tydeid $*$ fungicide $*$ year & 2,414 & $4.8 * *$ & 2,439 & 3.0 & 2,405 & 1.9 \\
\hline Random & $\mathrm{df}$ & $\chi^{2}$ & df & $\chi^{2}$ & df & $\chi^{2}$ \\
\hline Block & 1 & $76.2 * * *$ & 1 & $19.0 * * *$ & 1 & $7.1 * *$ \\
\hline
\end{tabular}

a $* * * P<0.001, * * P<0.01, * P<0.05$. 
most part, similar to effects on foliar infection. The presence of mites alone resulted in decreases in severity of mildew of 73 , 95 , and $86 \%$ on clusters for 2000,2001 , and 2002, respectively, averaged across grape cultivars (Fig. 2C). Powdery mildew fungicides alone were also quite effective, providing slightly better control than tydeid mites alone in 2000 (pairwise contrast, $\left.t_{564}=-3.34, P=0.0009\right)$ and less effective control than mites in $2001\left(t_{564}=\right.$ 7.73, $P<0.0001)$ and $2002\left(t_{562}=3.51, P\right.$ $=0.0005)($ Fig. $2 \mathrm{C})$. The combination of $O$. lambi and fungicide provided the best control in all 3 years, although the level of control was not statistically different from the mite-only treatment in 2001. The significant interaction between the mite treatment and the powdery mildew fungicide treatment (Table 1) indicates that the effects of mites and fungicide were not additive. There were large differences among grape genotypes in susceptibility to cluster infection (Table 1). Cultivars of $V$. vinifera were highly susceptible, while $V$. labrusca cultivars and most of the hybrid cultivars were highly resistant to cluster infection with the exception of 'Seyval' and to a lesser extent, 'Aurora' (Fig. 5). The significant interaction between the mite treatment and cultivar $\left(F_{9,217}=36.79\right.$, $P<0.0001)$ indicates the mites provided better control of cluster infection on some cultivars than others, and the significant three-way interaction with time indicates this varied among years $\left(F_{18,405}=3.39, P<\right.$ $0.0001)$. In particular, mites reduced cluster infection by $92 \%$ or more for $V$. vinifera cultivars while reducing infection by approximately $65 \%$ for 'Seyval' and 'Aurora'. Severity of cluster infection on the other cultivars was very low (below $1 \%$ ), with or without $O$. lambi.

Pruning mass. The presence of $O$. lambi alone or powdery mildew fungicides alone or a combination of mites and fungicide resulted in a significant increase in pruning mass over control vines that received neither mites nor powdery mildew fungicides in 2000 and 2001, but there were no differences among these three treatments (Fig. 6A, Table 2). Not surprisingly, the different cultivars varied significantly in pruning mass due to characteristic differences in growth habits (Table 2). There was no significant two-way interaction between cultivar and mite treatment, but there was a significant three-way interaction among cultivar, mite treatment, and year (Table 2). For 'Cabernet Franc', 'Cabernet Sauvignon', 'Niagara', the unnamed hybrid, and 'Seyval', there was a significant, positive effect of $O$. lambi release on pruning mass in one year but not the other. The benefit of powdery mildew fungicides on pruning mass also varied depending on cultivar, indicated by the significant interaction term (Table 2). In particular, powdery mildew fungicides increased pruning mass for 'Cabernet Sau-

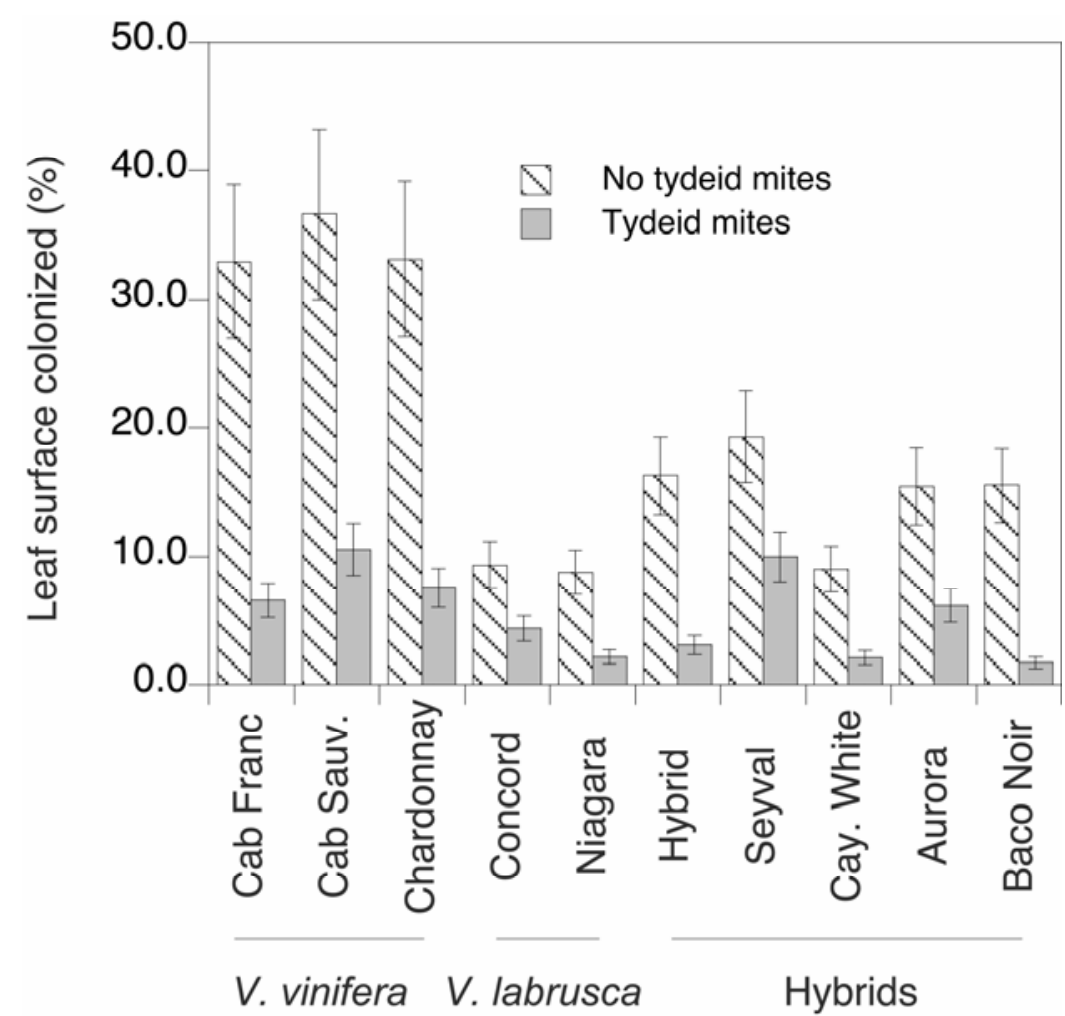

Fig. 4. Mean percentage of leaf area covered with grape powdery mildew on vines that received mycophagous tydeid mites Orthotydeus lambi (includes data for vines with and without powdery mildew fungicide) and vines where $O$. lambi was not released (includes data for vines with and without grape powdery mildew fungicide) for nine different grape cultivars and one unnamed hybrid over the 3 years data were collected (2000-2002). Mean values were computed by taking the anti-log of logtransformed values. Vertical bar indicates anti-log of $\log$ mean $\pm 1 \log$-transformed standard error.

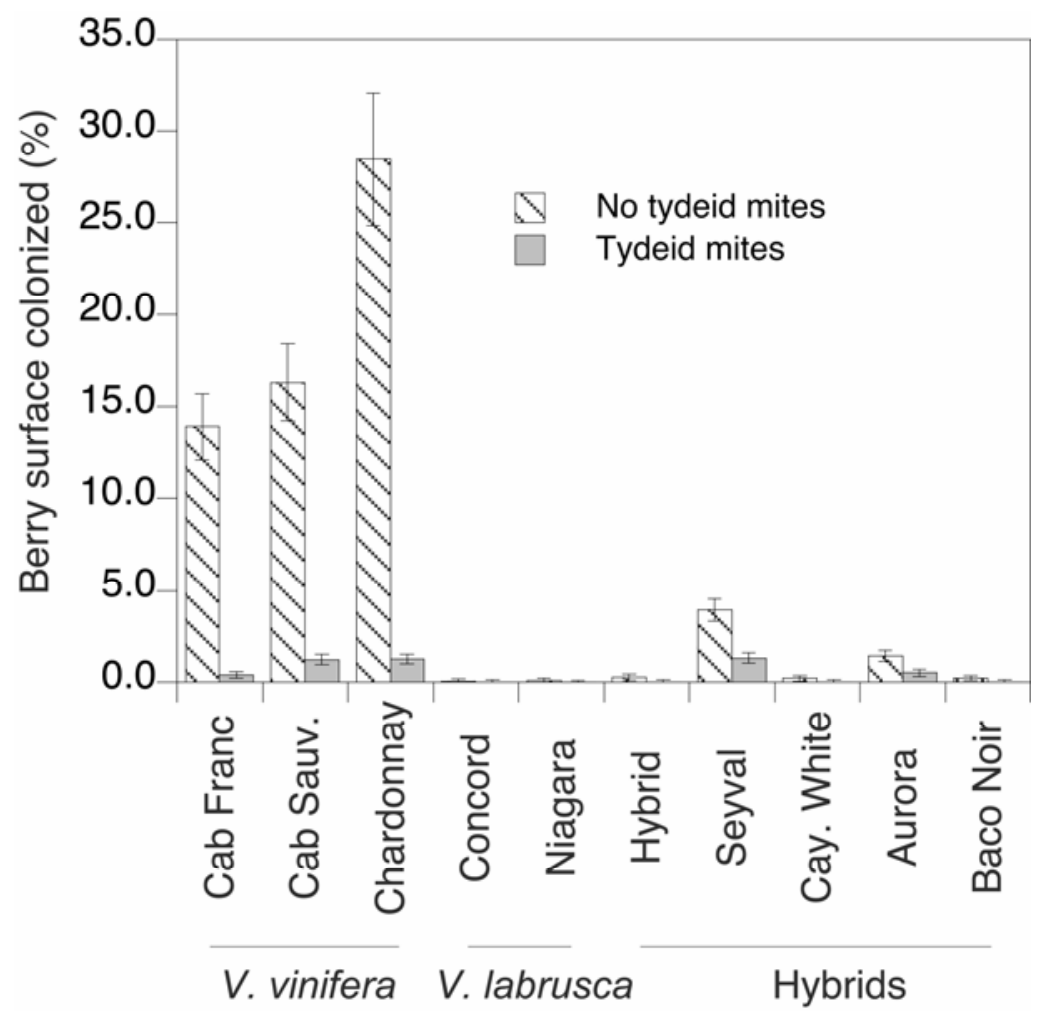

Fig. 5. Mean percentage of berry surface area covered with grape powdery mildew on vines that received mycophagous tydeid mites Orthotydeus lambi (includes data for vines with and without powdery mildew fungicide) and vines where $O$. lambi was not released (includes data for vines with and without powdery mildew fungicide) for nine different grape cultivars and one unnamed hybrid over the 3 years data were collected (2000-2002). The mean values were computed by taking the anti-log of $\log$-transformed values. Vertical bar indicates anti-log of log mean $\pm 1 \log$-transformed standard error. 
vignon', 'Chardonnay', and 'Niagara', while the fungicides did not translate into statistically significant larger pruning mass for the other cultivars.

Photosynthesis rates. Release of $O$. lambi, powdery mildew fungicides, and cultivar all significantly influenced leaf photosynthesis (Table 2). Release of $O$. lambi alone resulted in a $32 \%$ increase in leaf photosynthesis, while powdery mildew fungicides alone increased the rate by $42 \%$. The combination of fungicides and tydeid mites resulted in a $54 \%$ increase, but the two were not fully additive as reflected by the significant interaction between fungicide and mite release $\left(F_{9,176}=\right.$ $3.90, P=0.026)$. In addition to an overall effect of cultivar, there was a significant interaction between mite release and cultivar. The presence of mites resulted in a significant or marginally significant increase in photosynthetic rate for two of the three highly susceptible $V$. vinifera culti- vars ('Chardonnay': $t_{172}=-2.14, P<0.05$; 'Cabernet Franc': $\left.t_{175}=-3.28, P=0.001\right)$, the hybrid 'Baco Noir' $\left(t_{165}=-6.11, P<\right.$ $0.0001)$, and the unnamed hybrid $\left(t_{181}=\right.$ $-2.19, P=0.03)$ but not for the other cultivars.

Yield. Yield differences were consistent with differences observed for photosynthesis and pruning mass. Mites alone and powdery mildew fungicides alone resulted in significant increases in yield of 18 and $10 \%$, respectively (Fig. 6B, Table 2). The combination of mites and fungicide increased yield by $43 \%$, averaged over 2 years, indicating a synergistic effect (significant interaction between fungicide and mite release, Table 2). The influence of $O$. lambi on yield varied among cultivars, having a positive influence on the $V$. vinifera cultivars and two of the interspecific hybrids (the unnamed hybrid and 'Seyval') (Table 2, Fig. 7) and no significant effect for the other cultivars. The positive influ-
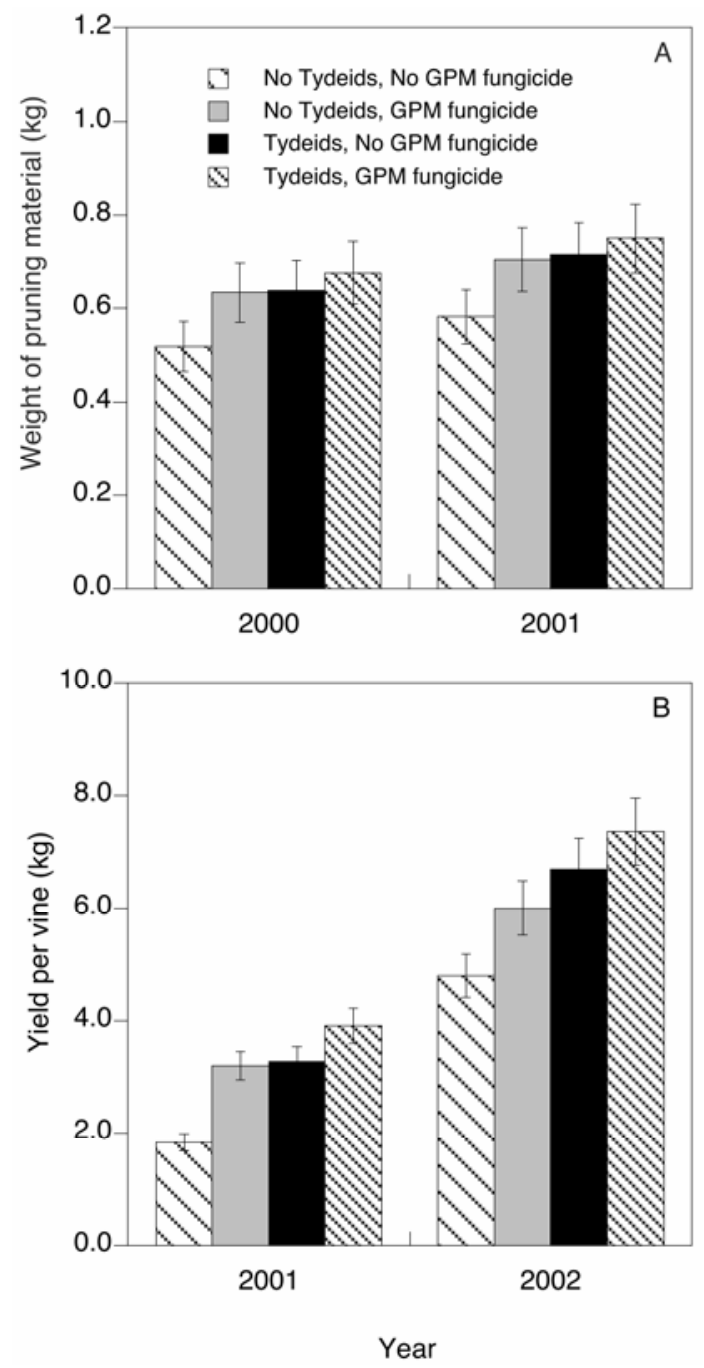

Fig. 6. A, Mean pruning weight for control vines without mycophagous tydeid mites Orthotydeus lambi or grape powdery mildew (GPM) fungicide, vines with only GPM fungicide, vines with only $O$. lambi, and vines with both $O$. lambi and GPM fungicide for 2000-2001. B, Mean yield for control vines without mycophagous tydeid mites $O$. lambi or GPM fungicide, vines with only GPM fungicide, vines with only $O$. lambi, and vines with both $O$. lambi and GPM fungicide for 2001-2002. Mean values were computed by taking the anti-log of log-transformed values. Vertical bar indicates anti-log of $\log$ mean $\pm 1 \log$-transformed standard error.

ence of powdery mildew fungicides on yield was also most pronounced for the $V$. vinifera cultivars, with increases ranging from $44 \%$ for 'Cabernet Franc' to $207 \%$ for 'Chardonnay' (Table 2).

\section{DISCUSSION}

We established the experimental vineyard to assess the potential of $O$. lambi for controlling grape powdery mildew under conditions more representative of commercial viticulture than our earlier studies. Entire vines of cultivars and an unnamed hybrid representative of those grown commercially in eastern North America and elsewhere were used. We evaluated survival of the mites on vines in the presence of repeated fungicide sprays designed to suppress not only grape powdery mildew, but other major fungal pathogens within the pest complex (27): downy mildew (Plasmopara viticola), Phomopsis cane and leaf spot and fruit rot (Phomopsis viticola), and black rot (Guignardia bidwellii). Over a 3-year period, the mites became well established on all cultivars and provided significant suppression of grape powdery mildew on both leaves and fruit. In fact, in many instances the degree of suppression provided by $O$. lambi was equivalent to that of the fungicide program used in this study. The magnitude of disease suppression provided by $O$. lambi under these conditions went beyond mere statistical significance, and was substantial enough to result in increased growth, photosynthesis, and yield relative to the no control treatment. The degree of suppression of powdery mildew by $O$. lambi on whole vines in the present study was generally greater than that reported in an earlier study involving isolated shoots of $V$. vinifera 'Chardonnay' and 'Riesling' (21). This represents one of the first field trials, outside of the greenhouse, where a biological control agent has provided a commercially acceptable level of suppression of grape powdery mildew. Our work involving suppression of grape powdery mildew by $O$. lambi is also the first welldocumented case wherein an arthropod has directly suppressed a plant disease.

A limited amount of interplot movement of mildew and mites is likely to have occurred in this experiment given the dispersal capabilities of these organisms, especially $U$. necator. The consequences of this movement would be to reduce treatment effects. Nevertheless, we observed a large impact of the tydeid mite treatment, fungicide treatment, and grape cultivar on mite numbers and mildew levels over several years, suggesting the treatment effects are large and significant.

The selective application of miticides used to prevent colonization of tydeid mites on "no mite" vines could have influenced the abundance of other species of mites that could, in turn, have influenced powdery mildew development. We did not 
observe significant numbers of phytophagous (plant-feeding) mites on any treatments during the 4 years. We did observe predatory mites (Family Phytoseiidae) on all treatment vines, although numbers tended to be higher on vines lacking tydeid mites (miticide-treated) for reasons that are not fully understood. Although phytoseiid mites such as Typholodromus pyri Scheuten, which was present in our experimental vineyard, are known to feed on some powdery mildews (35), there is no published evidence that this feeding suppresses disease. Moreover, numbers of phytoseiid mites were generally low, less than one per leaf for all treatments in all years. One other species of tydeid mite was found in the vineyard (tentatively identified as Homoprontomatus anconi (Baker)), but it was at low densities (less than two per leaf in 2000 and less than one per leaf for 2001 and 2002). Their numbers were essentially zero on miticide-treated vines, as was true for $O$. lambi. Their effect would probably be additive to $O$. lambi, as they have also been shown to reduce grape powdery mildew (A. P. Norton, unpublished data).

Our results clearly show the importance of grape cultivar in affecting the potential of $O$. lambi as a control for grape powdery mildew. This occurs at several levels, and there are a number of interesting interactions among cultivar, $O$. lambi, and $U$. necator.

First, some cultivars appear more suitable as habitats for $O$. lambi than others. Density of $O$. lambi on the Vitis interspecific hybrid grape 'Baco Noir' averaged more than 30 mites per leaf, while mean density on V. labrusca 'Concord' and 'Niagara', along with the Vitis interspecific hybrid 'Seyval', were consistently less than 10 per leaf. All else being equal, greater densities of $O$. lambi usu- ally resulted in greater suppression of grape powdery mildew, as shown in this study and in our previous work $(10,21,25)$. Although a number of factors may contribute to differences in density of $O$. lambi among cultivars, our previous research strongly indicates that the presence and size of domatia, tufts of nonglandular trichomes in the vein axils on the underside of leaves, are consis-

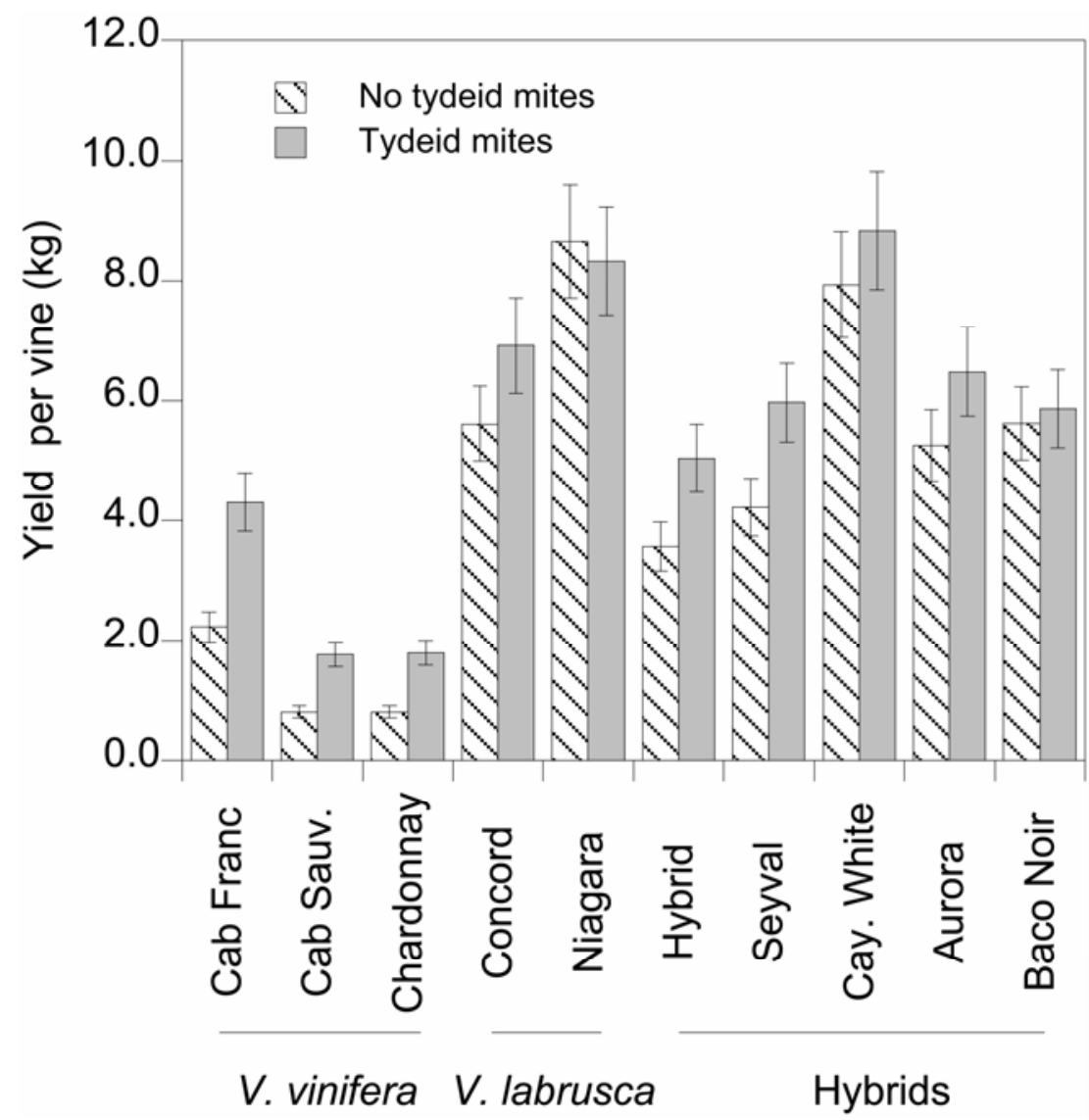

Fig. 7. Mean yield on vines that received mycophagous tydeid mites Orthotydeus lambi (includes data for vines with and without powdery mildew fungicide) and vines where $O$. lambi was not released (includes data for vines with and without powdery mildew fungicide) for nine different grape cultivars and one unnamed hybrid over the 3 years data were collected (2001-2002). Mean values were computed by taking the anti-log of log-transformed values. Vertical bar indicates anti-log of $\log$ mean \pm 1 log-transformed standard error.

Table 2. Mixed model repeated measures analysis of variance examining the effect of release of the tydeid mite Orthotydeus lambi, grape powdery mildew fungicide, grape cultivar, year, and interactions as fixed effects variables and block as a random effects variable on pruning weight, single leaf photosynthesis rate, and yield (pruning weight was natural-log transformed after adding 0.1 and yield was natural-log transformed to meet assumptions of ANOVA) for 2000-2001 (2001-2002 for yield only)

\begin{tabular}{|c|c|c|c|c|c|c|}
\hline \multirow[b]{2}{*}{ Source } & \multicolumn{2}{|c|}{ Pruning weight } & \multicolumn{2}{|c|}{ Photosynthesis rate } & \multicolumn{2}{|c|}{ Yield } \\
\hline & df & $F$ value & df & $F$ value & df & $F$ value \\
\hline \multicolumn{7}{|l|}{ Fixed } \\
\hline Tydeid mite release & 1,195 & $10.4 * * a$ & 1,176 & $30.3^{* * *}$ & 1,198 & $54.9 * * *$ \\
\hline Fungicide & 1,195 & $8.9^{* *}$ & 1,176 & $54.4 * * *$ & 1,198 & $35.0 * * *$ \\
\hline Grape cultivar & 9,195 & $40.8 * * *$ & 9,176 & $15.0 * * *$ & 9,198 & $96.0 * * *$ \\
\hline Year & 2,204 & $31.4 * * *$ & 1,174 & $6.1^{*}$ & 1,209 & $389.4 * * *$ \\
\hline Tydeid $*$ fungicide & 1,195 & 2.9 & 1,176 & $5.0^{*}$ & 1,198 & $8.2 * *$ \\
\hline Tydeid $*$ cultivar & 9,195 & 1.2 & 9,176 & $3.9 * *$ & 9,198 & $4.0^{* * *}$ \\
\hline Tydeid * year & 2,204 & 0.0 & 1,199 & $5.6^{*}$ & 1,209 & 2.6 \\
\hline Fungicide $*$ cultivar & 9,195 & $3.7 * *$ & 9,176 & 1.9 & 9,198 & $6.6^{* * *}-1-3-1$ \\
\hline Fungicide * year & 2,204 & 0.0 & 1,198 & 0.5 & 1,209 & $7.5^{* *}$ \\
\hline Year $*$ cultivar & 9,204 & $22.7 * * *$ & 9,199 & $6.7 * * *$ & 9,209 & $61.1 * * *$ \\
\hline Tydeid $*$ fungicide $*$ cultivar & 9,195 & 1.8 & 9,177 & 0.7 & 9,198 & 1.3 \\
\hline Fung. * year * cultivar & 9,204 & 1.6 & 9,198 & 1.8 & 9,209 & 1.4 \\
\hline Tydeid $*$ year $*$ cultivar & 9,204 & $2.3^{*}$ & 9,198 & 1.7 & 9,209 & $3.9^{* * *}$ \\
\hline Tydeid $*$ fungicide $*$ year & 1,204 & 0.0 & 1,199 & 0.5 & 1,209 & 2.7 \\
\hline Random & $\mathrm{df}$ & $\chi^{2}$ & df & $\chi^{2}$ & df & $\chi^{2}$ \\
\hline Block & 1 & $43.1 * * *$ & 1 & $14.1 * * *$ & 1 & $34.6^{* * *}$ \\
\hline
\end{tabular}

a $* * * P<0.001, * * P<0.01, * P<0.05$. 
tently positively related to density of $O$. lambi $(10,25)$.

Second, suitability of the cultivar as a habitat for $O$. lambi interacts with inherent level of susceptibility of a cultivar to $U$. necator to affect the magnitude of disease suppression. For example, the mite release treatment (both with and without fungicide) for 'Seyval', which is a relatively poor host for $O$. lambi and moderately susceptible to both foliar and fruit infection, resulted in a $48 \%$ decrease in leaf infection (19\% leaf area to $10 \%)$ and a $66 \%$ decrease in fruit infection (4\% berry surface area to $1.3 \%$ ). The mite treatment for 'Chardonnay', which is a relatively good host for the mite, but very susceptible to mildew, resulted in a $77 \%$ decrease in foliar mildew (33 to $7.6 \%$ ) and a $95 \%$ decrease in fruit infection (28.5 to $1.3 \%$ ). There was slightly more leaf mildew and about the same level of fruit infection on 'Seyval' with tydeid mites as on 'Chardonnay' with mites even though 'Chardonnay' had much higher levels of mildew than 'Seyval' when the mites were not present. As another example, the unnamed hybrid and 'Baco Noir' were equally susceptible to foliar mildew as 'Seyval' (16.3\% leaf infection without mites for the unnamed hybrid and $15.5 \%$ for 'Baco Noir'), but they were good to excellent hosts for $O$. lambi and, as such, had lower levels of leaf infection with mites present (the unnamed hybrid was $3.1 \%$ for an $81 \%$ decrease while 'Baco Noir' was $1.7 \%$ for an $89 \%$ decrease). Finally, the V. labrusca cultivars were not particularly good hosts for $O$. lambi, but they also were fairly resistant to leaf infection and had only trace levels of fruit infection. Hence, without mites, 'Concord' and 'Niagara' vines had 9.3 and $8.8 \%$ leaf infection, and with mites, vines had 4.4 and $2.2 \%$, respectively, well below levels on $V$. vinifera cultivars even though $V$ vinifera cultivars supported more $O$. lambi.

Infection of grape berries by $U$. necator is a serious problem in viticulture, especially in production of fine wines. Even small amounts can negatively affect wine quality (16). Thus, any control program, whether fungicide- or biologically based, must be highly effective against fruit infection. Highly susceptible cultivars, such as 'Chardonnay' and 'Cabernet Sauvignon', present a major challenge. Over the 3 years that powdery mildew on fruit was measured in this study, the mite-only treatment resulted in an average fruit severity of $2.3 \%$ for 'Chardonnay' and $1.6 \%$ for 'Cabernet Sauvignon' compared with 71 and $41 \%$ on unsprayed vines without mites. While the percent decrease in mildew was dramatic and possibly sufficient for commercial purposes, the mites were not always sufficiently effective without fungicides. In particular, in 2000 , the mite-only treatment resulted in about $9 \%$ cluster infection for 'Chardonnay' and 3\% for
'Cabernet Sauvignon' compared with 78 and $50 \%$ for the no control treatment. However, it is noteworthy that the fungicide program alone often provided less suppression of powdery mildew on fruit than the mites-only treatment on highly susceptible $V$. vinifera cultivars. Averaged over the 3 years, the fungicide-only treatment resulted in $11 \%$ cluster infection in 'Chardonnay' and 6\% in 'Cabernet Sauvignon'. While this outcome may partially reflect a steady erosion of the efficacy of the DMI fungicides fenarimol and myclobutanil due to resistance in $U$. necator in our experimental vineyard (12), it is nonetheless indicative of the benefits that can be obtained by preserving natural populations of tydeid mites in commercial vineyards, especially when fungicide efficacy is less than perfect due to resistance, improper timing, or incomplete spray coverage. Fungicide use in the presence of mites not only resulted in significantly better control of powdery mildew relative to mites alone or fungicide alone, control actually improved over the 3 years ("Chardonnay': $3 \%, 0.004 \%, 0.02 \%$ and 'Cabernet Sauvignon': $2.4 \%, 0.8 \%, 0.1 \%$ ) irrespective of fungicide efficacy as an isolated factor. Thus, presence of $O$. lambi enhances the impact of fungicides. Presently, however, fungicide use remains a necessary tactic to protect vines when the mite populations are low, and probably even when mite populations are high on certain cultivars.

Ironically, supplanting of the DMI fungicides by the strobilurin class, and the equally widespread tank-mixing of sulfur with strobilurins as an anti-resistance strategy, may partially destroy natural populations of $O$. lambi in commercial vineyards, as sulfur is highly toxic to O. lambi (9). Thus, to prevent losses due to resistance to strobilurins (32), growers may be forced to use a fungicide (sulfur) that is marginally more effective than the potential biocontrol that its use disrupts. There is a clear need for further research to explore ways in which necessary fungicide sprays can be deployed that cause minimal harm to $O$. lambi.

$O$. lambi appears to be at least as effective in reducing powdery mildew on fruit as on leaves. Averaged across the different genotypes, foliar powdery mildew in 2000 , 2001 , and 2002 was reduced by 59,87 , and $69 \%$, while severity of grape powdery mildew on berry clusters was reduced by 73,95 , and $86 \%$ during the same period. This is somewhat surprising since we typically observe $O$. lambi on leaves, frequently inhabiting domatia, and only infrequently on fruit clusters. Melidossian et al. (21) investigated grape powdery mildew severity on fruit clusters borne on selected shoots where $O$. lambi was prevented access to clusters. They found that the presence of $O$. lambi on the selected shoots significantly reduced severity of powdery mildew on berries whether mites had access to the clusters or not, perhaps by reducing levels of disease on adjacent leaves and thereby reducing contamination of the fruit clusters during their brief period of susceptibility to infection (15).

Weather conditions did vary over the 3 years of this study, and this likely influenced both mite and mildew abundance and possibly their interaction. Both mites and mildew are sensitive to temperature and relative humidity conditions during the growing season $(5,6,24)$. Moreover, $U$. necator needs free moisture to initiate primary infections in the spring. Given that these organisms probably do not have identical environmental tolerances, it is likely that some seasons would be more favorable for the biological control agent and others for grape powdery mildew. For instance, 2001 was warm and dry, especially in May and July, and not particularly good for the development of primary infections. On the other hand, mite abundance was high, and this may be attributable in part to weather (above-average growing degree days). In 2001, we observed the greatest proportional impact of mites on mildew. The 2000 season was cooler and wetter than 2001, and mite numbers were lower and disease pressure was higher, especially as measured by cluster infection.

Although our results are encouraging, there are a number of potential constraints to the use of $O$. lambi in commercial vineyards that need to be addressed. Although $O$. lambi can be quite abundant on native vegetation in the vicinity of vineyards, they are generally rare in vineyards (9). Probably the most significant reason for low natural colonization of vineyards is the incompatibility of $O$. lambi with some pesticides commonly used in viticulture to control diseases and arthropod pests. Our initial assessments found that mancozeb and sulfur-based fungicides, as well as the insecticide carbaryl, are quite toxic to $O$. lambi (9). Less-harmful alternatives exist but are generally more expensive, and there have been some significant problems with resistance. Another potential constraint to using $O$. lambi is achieving sufficient initial densities in the vineyard. For this experiment, we transferred mites from wild grapes onto young vines, but this is probably not practical for commercial purposes. Currently, we are conducting research on methods for rearing $O$. lambi in the laboratory as a requisite for inoculative or inundative releases. As discussed above, a related constraint has to do with abundance and complexity of domatia as a determinant of the suitability of cultivars as a host for $O$. lambi. In the long term, it may be possible to select for domatia in breeding or cultivar evaluation programs (11). We are also investigating methods to add artificial domatia-like structures to foliage. 
The success of a biological control agent can be measured in several ways: population of the agent and whether it equals or exceeds minimum effective levels, amount of plant injury compared with no control or an alternative chemical control tactic, and plant productivity compared with no control or an alternative. Vine productivity, particularly yield, in addition to crop quality, is a critical factor since adoption by growers requires that a control tactic produce economic benefits. Although more on-farm trials need to be conducted before this can be fully assessed, the results from our experiment are encouraging. We found that the mite-only treatment resulted in increased vine size, as estimated by pruning mass, photosynthesis rates, and yield compared with the no control treatment. The mite-only treatment and the powdery mildew fungicide treatment were roughly equivalent in terms of yield and other measures of productivity, but the combination of the two control tactics provided a significant increase in yield over either tactic alone. It is important to note that once established, the mites should provide their benefit at little cost to the grower other than choosing inputs that minimize disruption of the natural population.

\section{ACKNOWLEDGMENTS}

Steve Hesler managed the experimental vineyard and the many assistants involved in maintaining the field experiment and collecting data, for which we are very grateful. Kevin Conley, Suzy Fishel, Charolet and Andrea Gillespie, Carrie and Elizabeth Loomis, Jessica and Jason Nyrop, Charles Moser, Jenny Ogrodnick, Scott Rosencrans, Jeff Ugine, and Sara Villani provided, for one or more field seasons, the essential work force necessary to complete the project. They also contributed ideas, solved methodological problems, and helped create a truly enjoyable work environment. Françoise Vermeylen provided helpful assistance with statistical analyses. We would like to acknowledge the Plant Genetic Resource Unit of the USDA in Geneva, NY, Canandaigua Wine Company, and Santa Rosa Nursery for supplying cuttings for grape genotypes used in the experimental planting. M. Gleason and two anonymous reviewers offered numerous, helpful suggestions to improve the manuscript. This research was funded through grants from USDA CSREES Viticulture Consortium-East through a grant to Cornell University NYSAES, under Agreement \#34360-7382, New York Wine and Grape Foundation, NY State IPM Program, and the National Research Initiative of the USDA Cooperative State Research, Education and Extension Service, grant number 2001-35316-11039.

\section{LITERATURE CITED}

1. Agrios, G. N. 1997. Plant Pathology. 4th ed. Academic Press, San Diego.

2. Bélanger, R. R., and Benyagoub, M. 1997. Challenges and prospects for integrated control of powdery mildews in the greenhouse. Can. J. Plant. Pathol. 19:310-314.

3. Bélanger, R. R., and Labbé, C. 2002. Control of powdery mildews without chemicals: Pro- phylactic and biological alternatives for horticultural crops. Pages 256-267 in: The Powdery Mildews. R. R. Bélanger, W. R. Bushnell, A. J. Dik, and T. L. W. Carver, eds. American Phytopathological Society, St. Paul, MN.

4. Bélanger, R. R., Labbe, C., and Jarvis, W. R. 1994. Commercial-scale control of rose powdery mildew with a fungal antagonist. Plant Dis. 78:420-424.

5. Carroll, J. E., and Wilcox, W. F. 2003. Effect of humidity on the development of grapevine powdery mildew. Phytopathology 93:11371144.

6. Delp, C. J. 1954. Effect of temperature and humidity on the grape powdery mildew fungus. Phytopathology 44:615-626.

7. Dik, A. J., Verhaar, M. A., and Bélanger, R. R. 1998. Comparison of three biological control agents against cucumber powdery mildew (Sphaerotheca fulginea) in semi-commercial scale glasshouse trials. Eur. J. Plant Pathol. 104:413-423.

8. Duso, C., Pozzebon, A., Capuzzo, C., Malagnini, V., Otto, S., and Borgo, M. 2005. Grape downy mildew spread and mite seasonal abundance in vineyards: Effects on Tydeus caudatus and its predators. Biol. Control 32:143-154.

9. English-Loeb, G. M., Norton, A. P., Gadoury, D. M., Seem, R. C., and Wilcox, W. F. 1999. Control of powdery mildew in wild and cultivated grapes by a Tydeid mite. Biol. Control 14:97-103.

10. English-Loeb, G., Norton, A. P., Gadoury, D., Seem, R., and Wilcox, W. 2005. Tri-trophic interactions among grapevines, a fungal pathogen and a mycophagous mite. Ecol. Applic. 15:1679-1688.

11. English-Loeb, G., Norton, A., and Walker, M. 2002. Behavioral and population consequences of acarodomatia in grapes on phytoseiid mites (Acari: Mesostigmata) and implications for plant breeding. Entomol. Exp. Applicata 104:307-319.

12. Erickson, E. O., and Wilcox, W. F. 1997. Distributions of sensitivities to three sterol demethylation inhibitor fungicides among populations of Uncinula necator sensitive and resistant to triadimefon. Phytopathology 87:784-791.

13. Falk, S. P., Gadoury, D. M., Cortesi, P., Pearson, R. C., and Seem, R. C. 1995. Parasitism of cleistothecia of Uncinula necator by the mycoparasite Ampelomyces quisqualis. Phyopathology 85:794-800.

14. Falk, S. P., Gadoury, D. M., Pearson, R. C., and Seem, R. C. 1995. Partial control of grape powdery mildew by the mycoparasite Ampelomyces quisqualis. Plant Dis. 79:483-490.

15. Gadoury, D. M., Seem, R. C., Ficke, A., and Wilcox, W. F. 2003. Ontogenic resistance to powdery mildew in grape berries. Phytopathology 93:547-555.

16. Gadoury, D. M., Seem, R. C., Wilcox, W. F., and Henick-Kling, T. 2002. Effects of powdery mildew on bunch rots, berry microflora, and juice and wine quality. Pages 64-65 in: Proc. 4th Int. Workshop Grapevine Downy Powdery Mildew, Napa, California. UC Davis Press.

17. Gubler, W. D., Ypema, H. L., Ouimette, D. G., and Bettiga, L. J. 1996. Occurrence of resistance in Uncinula necator to triadimefon, myclobutanil, and fenarimol in California grapevines. Plant Dis. 80:902-909.

18. Hofstein, R., Daoust, R. A., and Aeschilmann, J. P. 1996. Constraints on the development of biofungicides: The example of "AQ10", a new product for controlling powdery mildews. Entomophaga 41:455-460.

19. Krantz, G. W. 1978. A manual of acarology. Oregon State University Book Stores, Corvallis.

20. Littell, R. C., Milliken, G. A., Stroup, W. W., and Wolfinger, R. D. 1996. SAS Systems for Mixed Models. SAS Institute, Cary, NC.

21. Melidossian, H. S., Seem, R. C., English-Loeb, G., Wilcox, W. F., and Gadoury, D. M. 2005 Suppression of grapevine powdery mildew by a mycophagous mite. Plant Dis. 89:1331-1338.

22. Mendel, Z., and Gerson, U. 1982. Is the mite Lorryia formosa a sanitizing agent in citrus groves? Acta Oecologia 3:47-51.

23. Moore, M. O. 1991. Classification and systematics of eastern North American Vitis L. (Vitaceae) north of Mexico. SIDAI 14:339367.

24. Norton, A. P., English-Loeb, G., and Belden, E. 2001. Host plant manipulation of natura enemies: Leaf domatia protect beneficial mites from insect predators. Oecologia 126:535-542.

25. Norton, A. P., English-Loeb, G., Gadoury, D. M., and Seem, R. C. 2000. Mycophagous mites and foliar pathogens: Leaf domatia mediate tritrophic interactions in grapes. Ecology 81:490-499.

26. Pearson, R. C., and Gadoury, D. M. 1991 Powdery mildew of grape. Pages 129-146 in: Plant Diseases of International Importance. Diseases of Fruit Crops, Vol. III. J. Kumar, H. S. Chaube, U. S. Singh, and A. N. Mukhopadhyay, eds. Prentice Hall, Englewood Cliffs, NJ.

27. Pearson, R. C., and Goheen, A. C. 1988. Compendium of Grape Diseases. American Phytopathological Society, St. Paul, MN.

28. Pool, R. M., Einset, J., Kimball, K. H., and Watson, J. P. 1976. Vineyard and cellar notes Spec. Rep. No. 22, N.Y. State Agric. Exp. Stn., Geneva, NY.

29. U.S. Dep. Agric. Nat. Agric. Stat. Serv. 1997. Agricultural chemical usage, fruit summary for 1997. USDA, Economics, Statistics, and Market Information System. Published online.

30. Verhaar, M. A., Kerssies, A., and Hijwegen, T. 1999. Effect of relative humidity on mycoparasitism of rose powdery mildew with and without treatments with mycoparasites. Zeitschrift Pflanzenkrankh. Pflanzenschutz 106:158-165

31. Verhaar, M. A., Ostergaard, K. K., Hijwegen, T., and Zadoks, J. C. 1997. Preventative and curative applications of Verticillium lecanii for biological control of cucumber powdery mildew. Bicontrol Sci. Technol. 7:543-551.

32. Wilcox, W. F., Burr, J. A., Reigal, D. G., and Wong, F. P. 2003. Practical resistance to Qo fungicides in New York populations of $U n$ cinula necator associated with quantitative shifts in pathogen sensitivities. (Abstr.) Phytopathology 93:S90.

33. Winkler, A. J., Cook, J. A., Kliewer, W. M. and Lider, L. A. 1974. General Viticulture University of California Press, Berkeley.

34. Wong, F. P., and Wilcox, W. F. 2002. Sensitivity to azoxystrobin among isolates of Uncinula necator: Baseline distribution and relationship to myclobutanil sensitivity. Plant Dis. 86:394 404.

35. Zemek, R. 2005. The effect of powdery mildew on the number of prey consumed by $T y$ plodromus pyri (Acari: Phytoseiidae). J. Appl. Entomol. 129:211-216. 